\title{
A Study on the Transformative Public Library Usage of the Second Semester Students of STKIP Muhammadiyah Enrekang
}

\author{
Ita Sarmita Samad*, Ismail Ismail \\ STKIP Muhammadiyah Enrekang, Indonesia
}

\section{ARTICLE INFO}

Article History:

Received 11 December 2018

Accepted 7 January 2019
Keywords:

Transformative Public Library, Primary School

Teacher Education, Usage,

Reading Interest

\begin{abstract}
This study was aimed at knowing the extent to which the use of the transformative public library of the second semester students of STKIP Muhammadiyah Enrekang. The subjects of the study were the second semester students of STKIP Muhammadiyah Enrekang in primary school teacher education department. The data was collected through interview. The result shows that the students use the transformative public library in three purposes. The first is as a media to do the assignment from the campus. The second is to read interesting books. The third is to participate in a book fair. Yet, there are some students who never use the facilities given by the public library since they never go there.
\end{abstract}

\section{INTRODUCTION}

Public Library simply means a place where the society can read or borrow some books or other kinds of literature. According to oxford dictionary, it is collection of books, records, etc. Similarly, Bafadal in Prastowo (2012) stated that a library is a unit of a certain institution which manages the literary forms, either book or non-book material that systematically administered based on certain rules thus can be used as information sources for the users.

The definitions of library mentioned above are relevant with the condition of Enrekang Public Library some years ago. That is a building collecting many books where users can read or borrow. Consequently, the people who come there are only they who are interested in reading. Meanwhile, some studies showed that Indonesian people have low interest in reading including Enrekang. As a result, there is only a few users come to the library.

The writer had interviewed one of the librarians. She stated that the condition of the library seemed careless at that time. The collection, the librarian, and the room design could be the factors that made it. The users might be lazy to go to the library since the books there were out of dated. Besides, most of the librarian showed their unsupportive

@Majesty Journal 2019 
attitude. They were described as lazy and unfriendly. Moreover, the library room was not well-designed.

The library was also described as a unit or institution which was often underestimated in the government system. Frequently, the civil servants who did a violation would be transferred to the library office as a punishment for them. In some cases, the civil servant who got sick and made him/her could not go to the office intensively; he/she would be transferred to the library office as well. Accordingly, the library was seen as an exile office.

The transformative library of Enrekang started in 2013 when Bill and Mellinda gates foundation in collaboration with Coca-Cola Foundation offered partnership to the library. They proposed a program called Perpuseru. The concept is designing the library not only as reading center as usual but also as information and forefront center for the society. The goal is to increase the prosperity of the society with technology, information and communication based.

There are three main strategies used to be transformative library. The first is the strategy of technology information and communication services through free $\mathrm{Wi}-\mathrm{Fi}$ access. The second is the strategy of the society engagement. The third is advocacy strategy.

The library sets up free Wi-Fi access for the users. It is a strategy to make the society becomes accustomed with the use of internet. As a result, they can utilize it in facilitating their need, their job, etc.

The society engagement strategy is used to help the society or community whoever wants to hold an activity in the library. The library identifies the problems are around the society which can be facilitated. It can be in the field of health, business, education, hobby, etc.
For instance, it was identified that the businessmen in Enrekang had difficulties in marketing. Thus, the library attempted to facilitate them by conducting a seminar or workshop on internet marketing. The result is always followed up. It was identified that there are some people who have got benefit from the activity. One of them is a man who sells dangke (a special food of Enrekang). He gives testimony stated that after following the workshop on internet marketing, his turnover is rise. His profit is up to Rp. $1.000 .000 /$ day. Even, his products have been also sent to overseas like New Zealand and Malaysia.

Another form of the society engagement is inviting a person or figure of Enrekang who has a name in local or national. The aim is to share their ideas with the society. The library position is to provide the sharing class. There are some classes that have been run. The class had been done to facilitate how to be a good YouTube, writer, businessman, etc.

Advocacy strategy is the way to lobby the government or private institution whoever has the right to change the policy as a mean to support the public library. For instance, if the government policy toward the estimated funding for the library is not enough then it is the time to do this strategy. The library attempted to influence the government to increase the funding. Another example ever showed by private institution. Once, there is a coloring competition held in library. Since there was no funding allocated in that activity thus the library had an advocacy with a private institution called Gugah Nurani Indonesia. Then they gave support in terms of providing coloring pencils.

The fact shows that the transformative library gives a positive impact to the society. However, the writer was curious to know the extent to which the use of the transformative public library of the second semester students of STKIP Muhammadiyah Enrekang. Remind that the students also as a part of the society. 


\section{LITERATURE REVIEW}

Bhatty (2013) concluded that the basic purposes of most of the users entered to the faculty library were education, research work, and updating knowledge. However, they preferred use the internet services to the books. In addition, they were dissatisfied in some services. The journals subscription related to their discipline were not up to date and the internet services were not fully providing.

Kumah (2015) analyzed a comparative study on library and internet usage. She found that the students did not neglect the use of the library as a source of information. Yet, they prefer to use the internet at this point. It was suggested to upgrade the library in order to reach the recent progression in study.

Tiemo and Ateboh (2016) studied about the users' satisfaction with library information resources and services. They concluded that there were some points that the users are satisfied with. They were in terms of book lending, library materials, and internet services. However, the users were dissatisfied with the reference materials related to their field of subject, national and international journals. Those things are limited and not up to date.

\section{METHODOLOGY}

\section{Participants}

The participants of this study were chosen randomly. They were the second semester students of Primary School Teacher Education Department of STKIP Muhammadiyah Enrekang. They were in Class

A. They consisted of 18 students; 5 men and 13 women.

\section{Data collection}

The data was collected through interview. It consisted of 18 questions. The interview was used to explore the participants' position toward the use of transformative public library.

\section{Results and Discussion}

The findings show that there were 7 of 18 students who did not ever go to the public library. Meanwhile, 11 of 18 students ever go there rarely. It implies that the students had low interest in using the library as a mean of information and forefront center.

The students who have not entered to the library uttered some reasons. Some of them were busy since they also have side job thus they have no time for library. A student also admitted that he indeed has low interest in reading (Ismail, I., Busa, Y., \& Tini, T. (2018), therefore he is lazy to go the library. Another reason also expressed by some of the students. They said that they once came to the library but it was closed and thus they were idle to come again.

The reasons uttered indicated at least two points. The first is the students' mindset toward the library is still the same with the old term which is only a place to read or borrow books. They might not know that the public library have been transformed into the new form thus have other new functions. The second is the students might no interest in utilizing the public services toward regarding information sources. They prefer to do by their private facility like smart phone.

There were 9 of 11 students who go to the library rarely expressed that they go there in order to accomplish a campus assignment. They looked for related books yet they use the internet facility at most. This is similar with the result of the study conducted by Kumah (2015) which found that students prefer to use the internet but they did not neglect the use of the library as a source of information.

However, some of the students complained with the internet hour which is too short. It is limited to only 30 minutes used. 
Thus, when the time is over they usually go home.

Another data showed that there were only 2 students who go to the library by themselves. They indeed come to read the books they were interested in. They did not come only because they wanted to accomplish a group assignment like other students do. It means the students had more interest in reading than the other students do.

In terms of exploiting another program of the transformative library which concerns on the society engagement, the data showed that there was only 1 student who ever joined. He attended the book fair in "Pekan Literasi" program. He joined that program with his friends as a way to hang out.

\section{CONCLUSIONS}

The students use the transformative public library in three purposes. The first which is the main purpose is to accomplish their assignment. The second is to explore their reading interesting. However, there were a very little percentage of the students did that. The third is to participate in a book fair which was only used by one student. Yet, there were some students who never use the facilities given by the public library since they never go there.

\section{Suggestions}

1. The librarian may do some programs in collaboration with the students of STKIP Muhammadiyah Enrekang as a mean of introducing the transformative library to them. Hence, they can utilize the library in many aspects.

2. The librarian is suggested to extend the internet hours. Thus, the students can stay for longer time in the library.

3. The lecturers may support the literary move by suggesting their students to use the facilities given in the library.
4. The recent study was done for the second grade students of primary school teacher education department. Thus, it is suggested to the next researcher in this field to study in other departments.

5. The further researchers are also suggested to study about the influence of sex and age of the participant toward the use of public library.

\section{REFERENCES}

[1] Bhatty, R. (2013). A study of library usage

and satisfaction by social scientist at bahauddin zakariya university, multan. EJournal of Library Philosophy and Practice. Retrieved from https://www.researchgate.net/publicati on/280049015

[2] Kumah, C. H. (2015). A comparative study of use of the library and the internet as sources of information by graduate students in the University of Ghana. E-Journal of Library Philosophy and Practice. Retrieved from https://www.researchgate.net/publicati on/286489608

[3] Prastowa, A. (2012). Manajemen perpustakaan sekolah professional. Jogjakarta, Indonesia: DIVA Press.

[4] Ismail, I., Busa, Y., \& Tini, T. (2018). Parental involvement in fostering the character of children's discipline at elementary school. Jurnal Pendidikan Progresif, 8(2), 53-67.

[5] Tiemo, P. A., \& Ateboh, B. A. (2016). Users' satisfaction with library information resources and services: a case study college of health sciences library Niger-delta University, Amasova, Nigeria. E-Journal of Education and Practice, 7 (16), 54-59. 
Majesty Journal, 1 (1), 2019 - 5

Ita Sarmita Samad 